\title{
Assessment of T1rho relaxation times after reperfused myocardial infarction
}

Marie Madden², Shahid Mohammed², Francisco Contijoch², James J Pilla², Joseph H Gorman', Yuchi Han², Robert C Gorman', Walter R Witschey ${ }^{2^{*}}$

From 19th Annual SCMR Scientific Sessions

Los Angeles, CA, USA. 27-30 January 2016

\section{Background}

T1 $\rho$ MRI is an emerging method for high spatial resolution tissue characterization of myocardial infarct (MI), but the evolution of $\mathrm{T} 1 \rho$ in the first month after reperfused MI is uncertain. We conducted a study of reperfused MI in pigs to serially monitor T1 $\rho$ relaxation times at baseline, 1 and 4 weeks post-MI and correlated these results with $\mathrm{T} 2$, native $\mathrm{T} 1$, and histological findings.

\section{Methods}

13 pigs underwent 90 minutes of occlusion of the circumflex artery branches. T1 $\rho, \mathrm{T} 2$ and native T1 MRI
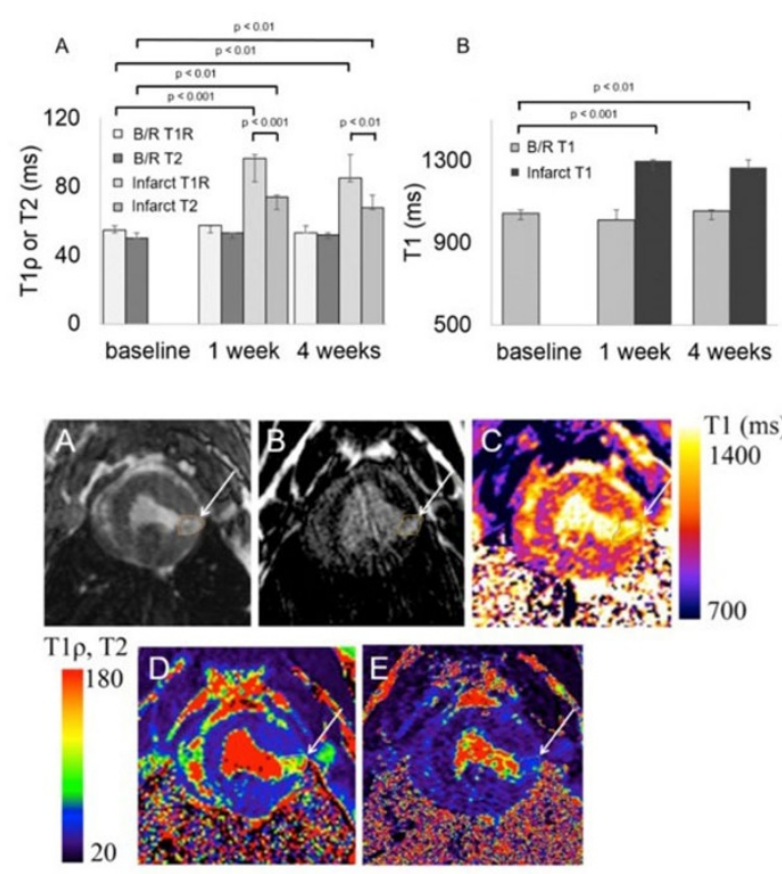
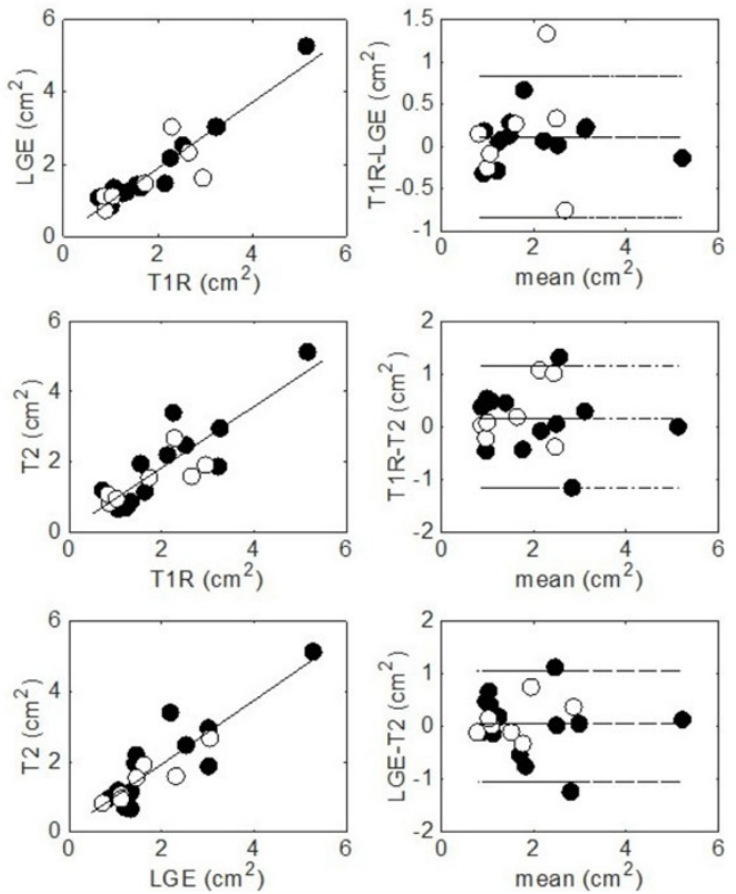

Figure 1

${ }^{2}$ Radiology, University of Pennsylvania, Philadelphia, PA, USA

Full list of author information is available at the end of the article 
data were collected at terminal 1 week $(n=6)$ and 4 weeks $(\mathrm{n}=7)$ post-MI studies. $2 \mathrm{D}$ T1 $\rho$ single-shot balanced steady-state free precession (bSSFP) sequences were performed using a spin echo, spin lock T1 $\rho$ pulse cluster $\left(90_{\mathrm{x}}-\mathrm{SL}_{\mathrm{y}}-180_{\mathrm{y}}-\mathrm{SL}_{-\mathrm{y}}-90_{-\mathrm{x}}\right)$ with the following parameters: TSL $=2-50 \mathrm{~ms}, \mathrm{~B}_{1}=500 \mathrm{~Hz}$. T2 MRI was obtained $90_{x}-180_{y}-90_{-x}$ using the same readout parameters. T1 maps were obtained with a modified LookLocker sequence (MOLLI WIP sequence \#448B, 5-3-3, Siemens), utilizing a single-shot acquisition with 8 inversion times. For LGE MRI, the animal received $0.1 \mathrm{mmol} /$ $\mathrm{kg}$ intravenous injection of gadolinium contrast (MultiHance). Late-gadolinium enhanced (LGE) MRI was obtained using a 3D multishot phase-sensitive inversion recovery (PSIR) sequence with bSSFP spatial encoding. Ex vivo MRI and histology was performed at each terminal time point. Fibrotic tissue was assessed with trichrome staining. In vivo MRI was spatially correlated with ex vivo imaging and histopathology.

\section{Results}

Infarct T $1 \rho$ increased 39.0 (1 week) and $32.1 \mathrm{~ms}$ (4 weeks) and T2 increased $21.0 \mathrm{~ms}$ (1 week) and 16.2 (4 weeks) after infarction. In vivo T1 $\rho$ was longer than $\mathrm{T} 2$ in normal (baseline), remote and infarcted tissue at 1 and 4 weeks $(\mathrm{p}<0.05)$. Native T1 increased 288.0 and $212.4 \mathrm{~ms}$ at 1 and 4 weeks post-infarction $(\mathrm{p}<0.05)$. The percent increase in $\mathrm{T} 1 \rho, \mathrm{T} 2$ and $\mathrm{T} 1$ from baseline was 76,48 and $24 \%$ at 1 week and 56,36 and $21 \%$ at 4 weeks in the infarct region. T1 $\rho$ post-infarction area at 1 week was highly correlated with infarct fibrosis $(\mathrm{p}<0.05)$.

\section{Conclusions}

T1 $\rho$ relaxation times were highly correlated with alterations in post-MI pathology at 1 and 4 weeks and therefore it may be a useful method for non-contrast enhanced imaging of infarction.

\section{Authors' details}

${ }^{1}$ Surgery, University of Pennsylvania, Philadelphia, PA, USA. ${ }^{2}$ Radiology, University of Pennsylvania, Philadelphia, PA, USA. ${ }^{3}$ Medicine, University of Pennsylvania, Philadelphia, PA, USA.

Published: 27 January 2016

doi:10.1186/1532-429X-18-S1-W13

Cite this article as: Madden et al.: Assessment of T1rho relaxation times after reperfused myocardial infarction. Journal of Cardiovascular Magnetic Resonance 2016 18(Suppl 1):W13.

\section{Submit your next manuscript to BioMed Central} and take full advantage of:

- Convenient online submission

- Thorough peer review

- No space constraints or color figure charges

- Immediate publication on acceptance

- Inclusion in PubMed, CAS, Scopus and Google Scholar

- Research which is freely available for redistribution

Submit your manuscript at www.biomedcentral.com/submit 